\title{
Impact of Coronavirus Pandemic on Financial Market Stability in Africa
}

\author{
Wpływ pandemii koronawirusa \\ na stabilność rynków finansowych w Afryce
}

\author{
Kalu O. Emenike \\ University of Eswatini, Department of Accounting and Finance, Private Bag No 4, \\ Kwaluseni M201, Kingdom of Eswatini \\ E-mail: kalu@uniswa.sz, ORCID: 0000-0002-3599-0281
}

\begin{abstract}
The outbreak of the coronavirus in December 2019, with its accompanying declaration as a pandemic by the World Health Organisation in March 2020, resulted in lockdown of the global financial markets. This paper uses data from pre-coronavirus, coronavirus endemic and coronavirus pandemic periods to evaluate the impact of coronavirus pandemic on stability of Africa stock markets, sovereign bond markets and U.S. dollar exchange rates in Kenya, Morocco, Nigeria and South Africa as well as Africa Sharia equity and Sukuk indices. Findings from study suggest that Africa financial markets became very unstable during the coronavirus pandemic than during the endemic and pre-coronavirus periods. Results from bivariate regression model show evidence of negative impact of coronavirus pandemic on financial market returns. The results further show that Africa financial markets return volatility increases as the number of coronavirus cases increases. Overall, the findings suggest that coronavirus has negative impact on financial markets' returns and exacerbated financial markets instability thus retarding sustainable economic development in the continent.
\end{abstract}

JEL Classification Numbers: G10, I12, O55

Key words: Coronavirus, COVID-19, stock market, sovereign bond market, exchange rates, volatility, skewness, market stability, Africa

\section{Streszczenie}

Pojawienie się w grudniu 20129 r. koronawirusa, wraz z ogłoszeniem przez Światową Organizację Zdrowia w marcu 2020 r. pandemii, spowodowało zablokowanie światowych rynków finansowych. W niniejszym artykule wykorzystano dane z okresów przed koronawirusem, koronawirusa endemicznego i pandemii koronawirusa do oceny wpływu pandemii koronawirusa na stabilność afrykańskich giełd papierów wartościowych, rynków obligacji skarbowych i kursów dolara amerykańskiego w Kenii, Maroko, Nigerii i RPA, w powiazaniu z zasadami szariatu i indeksu Sukuk. Wyniki badań sugerują, że rynki finansowe w Afryce podczas pandemii koronawirusa stały się bardzo niestabilne, o wiele bardziej niż w okresie endemicznym i przed koronawirusem. Wyniki dwuwymiarowego modelu regresji wskazują na negatywny wpływ pandemii koronawirusa na zwroty z rynków finansowych. Wyniki pokazują ponadto, że zmienność zwrotów na afrykańskich rynkach finansowych rośnie wraz ze wzrostem liczby przypadków koronawirusa. Ogólnie rzecz biorąc, wyniki sugerują, że koronawirus ma negatywny wpływ na zyski na rynkach finansowych i zaostrza niestabilność rynków finansowych, opóźniając tym samym zrównoważony rozwój gospodarczy na kontynencie.

Slowa kluczowe: koronawirus, COVID-19, giełda, rynek obligacji skarbowych, kursy walut, zmienność, skośność, stabilność rynku, Afryka 


\section{Introduction}

Financial market stability is indispensable to sustainable economic development, especially in Africa developing economies. Financial market is crucial in promoting economic sustainability, by facilitating the flow of funds from the surplus to the deficit units of an economy. It provides access to a neutral reference price, reduces transaction costs through easy access to buyers and sellers in a centralized market place, and manage transaction risks, thus facilitate conservation of wealth and smooth functioning of economic activities (Stiglitz, 2010; Emenike, 2017; Kremen, Shkolnyk, Semenog \& Kremen, 2019). Each of these functions can be inconvenient for certain market participants, without stable financial market. Batuo, Mlambo, and Asongu (2017) conclude amongst others, that economic growth reduces financial instability. Indeed, stable financial markets are not only resilient but also a key factor in producing high economic growth. Financial market instability, on the other hand, retards conservation of financial resources, impedes economic activity and weakens sustainable economic development as prices for key financial assets deviate significantly from their intrinsic values. The financial market in such a situation, is not capable to absorb real economic shocks and to conserve financial resources on long-term scale.

The outbreak of coronavirus in December 2019, with its accompanying declaration as a pandemic by the World Health Organisation (WHO) on March 11, 2020 resulted in lockdown ${ }^{1}$ of the global economy. The lock-down of all businesses and organisations disrupted production, supply chain, and financial market activities. This resulted in huge decline in African governments' revenues and exacerbated vulnerability to coronavirus crisis. More so, there has been intensive pressure on governments to increase expenditure on palliatives and health equipment in order to mitigate impact of the pandemic (Ito, 2020; Goodell, 2020). The resulting liquidity pressure has become a threat to sustainable economic development and financial stability in the continent, as the fiscal capacity of African countries to respond to such crisis situations was low even before the pandemic. While the number of coronavirus cases and deaths appear comparatively low in Africa than in other world regions ${ }^{2}$, the economic damage inflicted on the continent is unprecedented. Indeed, the rapid global spread of Covid-19 and the high infection

\footnotetext{
${ }^{1}$ While there is enough evidence in history to show that diseases do affect the trajectories of nations, Africa has not witnessed a plague that resulted in simultaneous lockdown of almost all countries in the continent. COVID-19 is unprecedented in scale. The outbreak of Ebola, for example, did not result in shutting down the regional economies. There have been so many other outbreaks, including Asian bird flu, Spanish flu, SARS, HIV-Aids, etc., but none of them resulted in global lockdown.
}

rates raised fears of a global financial market crash in the endemic stage of the virus outbreak.

In response to the coronavirus threat, Africa governments unveiled different countermeasures to mitigate its impact on economic sustainability and financial stability in the continent. The Nigeria central bank in March 2020, amongst other measures, place a one-year extension of a moratorium on principal repayments on the bank's intervention facilities, and reduced interest rate on intervention loans from $9 \%$ to 5\%. Between April and May 2020, South African reserved bank reduced its main lending rate by 50 basis points to $3.75 \%$, and purchased government bonds worth 11.4 billion rand. In the same vein, the central bank of Kenya, amongst other measures, eliminated bank charges for transactions between a bank account and a mobile wallet, and increased the maximum limit for money transfers by mobile phone for small and medium enterprises. The government of Morocco established a pandemic management fund to support the national economy, including the suspension of social charges and repayment of bank loans by companies (MFW4A tracker, 2020). The announcement of these significant policy stimulus package enhanced the upside potential for financial market prices, even though market risks remained elevated (Topcu \& Gulal, 2020).

The importance of financial markets in mobilising resources, reducing information asymmetry, pricing risk and stimulating sustainable economic development is well established in literature (see for example, Colombage, 2009; Murinde, 2012; Wu, et al., 2020). But COVID-19 pandemic has significantly threatened financial markets stability (Ali, Alam \& Rizvi, 2020). African currencies, for example, came under pressure, with sharp exchange rate depreciations in more than half of the countries (Armah, 2020). Borrowers across sectors and scales of businesses have been affected by lock-down, as decline in their income and revenue has negatively impacted their loan obligations. The banking industry in Africa is threatened by the likelihood that there will be a sharp increase in non-performing loans, from the already high levels of $11 \%$ in 2019 (Tyson, 2020). Obeid and Ismail (2020) reports that stock markets around the world suffered trillions of US dollars losses in a single week in what was the markets' worst week since the financial crisis of 2008. Stock markets in the Euro area and the United States lost around $35 \%$ of their value between their peak on 19 February and their trough on 23 March (Ampudia,

\footnotetext{
${ }^{2}$ By $31^{\text {st }}$ August 2020, Kenya, morocco, Nigeria, and South Africa, for example, have 34057, 61,399, 53,865, and 625056 total number of COVID-19 cases respectively. It is only South Africa that has comparable figure to high cases countries such as the USA $(5,997,163)$, Brazil $(3,862,311)$, and Russia $(990,326)$ and Peru $(647,166)$ as at the same date.
} 
Baumann \& Fornari, 2020). Budget deficits have equally widened across the globe, thus increasing the need for sovereign bond financing. Giving the negative reports across the global financial markets, understanding the impact of coronavirus on Africa financial markets stability is relevant for entrenching and sustaining measures to reduce vulnerability to global shocks, guiding against future health crisis, and building economic sustainability and resilience. The purpose of this paper is to analyse the impact coronavirus on financial markets stability in Africa. The paper provides evidence on the behaviour of African financial markets during the pre-coronavirus era, coronavirus endemic era and coronavirus pandemic era using skewness, minimum and maximum returns as well as volatility of returns analysis. The comparative analysis deepens our understanding on the impact of the pandemic on financial market stability in Africa and provides basis for formulating policies that will minimise vulnerability to the current pandemic shocks as well as guide against future health crisis. The rest of this paper is structured as follows. Section 2 presents literature review. Section 3 focuses on method of analysis and data. Section 4 discusses the results, and Section 5 concludes the paper with few policy implications.

\section{Literature review}

While numerous studies are currently being conducted on the COVID pandemic, the available literature is nascent and growing. A few of the available literature assessed reaction of global financial markets return and volatility to Coronavirus pandemic. Ali, Alam and Rizvi (2020), for example, reported that returns of most of the financial securities are negatively and significantly related to the COVID19 deaths, but the volatility of most of the securities are positively related to the deaths. Similarly, Benzid and Chebbi (2020) reported that an increase of the number of cases and the deaths in the US has a positive impact on the USD/EUR, USD/Yuan and USD/LivreSterling. The findings of these studies suggest that financial assets become more volatile as the number of COVID-19 deaths increases.

Ito (2020) showed that, during the pandemic crisis, the stress in the financial system was connected in Germany, France, Italy, Portugal, and Spain. Akhtaruzzaman, Boubaker, and Sensoy (2020) showed that returns of listed financial and non-financial firms across China and G7 countries experience significant increase in conditional correlations during the COVID-19 period, but that the magnitude of increase is considerably higher for financial firms, indicating their importance in volatility transmission. In an emerging stock markets analysis, Topcu and Gulal (2020) reported that the COVID-19 pandemic has a negative impact on emerging stock markets but that the negative impact has gradually fallen and started to narrow by mid-April. The finding of this study brought an element of good news to financial market participants when it evince that the negative impact of the pandemic has started to taper.

Several studies have also been conducted to identify safe haven investment in the financial markets during the COVID-19 pandemic. Mirza, Naqvi, Rahat and Rizvi (2020) demonstrated that while most of the investment funds in Europe exhibit stressed performance, social entrepreneurship funds endured resilience during the various stages of evolution of the coronavirus pandemic. Conlon, Corbet and McGee (2020) reported that Bitcoin and Ethereum are not a safe haven for the majority of international equity markets examined, but that Tether acted as a safe haven investment by successfully maintaining its peg to the US dollar during the COVID-19 turmoil. Lahmiri and Bekiros (2020) evinced that cryptocurrencies were unstable and more irregular during the COVID-19 pandemic compared to international stock markets. Similar findings were reported by Conlon and McGee (2020). These analyses suggest that investing in digital assets during COVID-19 pandemic could be riskier than investing in equities. A number of studies have examined the interaction between media reportage and financial markets behaviour, especially during crisis periods. Tetlock (2007), for example, reported, amongst others, that high media pessimism predicts downward pressure on financial market prices followed by a reversion to fundamentals. Engelberg and Parsons (2011) evinced that local media coverage strongly predicts local trading. Similarly, Peress (2014) demonstrated that the media contributes to the efficiency of stock market by improving the dissemination of information among investors and its incorporation into stock prices. These findings on the linkage between media and financial market behaviour have largely shown that prices and market volatility respond to news reportage. Again in the pandemic era, sentiment generated by coronavirus-related news may have contributed to the rapid spread of fears of a global financial market crash, which heightened volatility of financial market prices. This statement is supported in a recent study by Haroon and Rizvi (2020), who found that overwhelming panic generated by the news outlets are associated with increasing volatility in the equity markets.

\section{Research methodology}

To analyse the impact of coronavirus on stability of Africa financial markets, descriptive statistics, EGARCH $(1,1)$ model and bivariate regression model were estimated. Specifically, financial asset return skewness and volatility were adopted as 
measures for financial market stability ${ }^{3}$. The skewness coefficients for the financial markets return series were compared in the three sub-periods of the study - pre-coronavirus, coronavirus endemic and pandemic periods. The exponential GARCH $(1,1)$ model introduced in Nelson (1991), were adopted to estimate volatility of African financial markets return, and bivariate regression model was employed to estimate the impact of total number of coronavirus cases on returns and volatility of African financial markets. The E-GARCH $(1,1)$ model introduced asymmetric parameter, which responds to positive and negative shocks, as a modification to the symmetric GARCH $(1,1)$ model. The EGARCH $(1,1)$ model was estimated using the following equation:

$$
\log \sigma_{t}^{2}=\omega+\alpha 1\left(\left|\frac{\varepsilon t-1}{\sqrt{\sigma_{t-1}^{2}}}\right|-\sqrt{\frac{2}{\pi}}\right)+\beta \log \sigma_{t-1}^{2}+\gamma\left|\frac{\varepsilon_{t-1}}{\sqrt{\sigma_{t-1}^{2}}}\right| \text { (1) }
$$

The $\log \sigma_{t}^{2}$ is the volatility at time $t, \omega$ is constant variance, $\alpha 1$ is first order ARCH term, $\beta 1$ is first order GARCH term, and $\gamma$ is asymmetric parameter that measures the nature of impact of shock on financial markets' return volatility. The bivariate regression model to estimate the impact of total number coronavirus cases on returns and volatility of African financial markets was specified as follows:

$P r_{i, t}=\alpha+\beta T C C_{c, t}+\varepsilon_{i, t}$

where $P r_{i, t}$ is as defined in equation $3, \beta T C C_{c, t}$ is the parameter for change in total coronavirus cases for country $c$ at time $t$, and $\varepsilon_{i, t}$ is the residual term. Statistically significant $\beta T C C_{c, t}$ coefficient would indicate evidence against absence of coronavirus impact on African financial markets return or volatility. Statistically insignificant $\beta T C C_{c, t}$ coefficient, on the other hand, would indicate support for absence of coronavirus impact on African financial markets return or volatility.

To estimate the models outlined above, we collected daily observations of Africa stock indices ${ }^{4}$, sovereign bond indices ${ }^{5}$, and Africa currencies/US dollar exchange rates ${ }^{6}$ as well as Sharia and Sukuk indices. In addition, we selected four African countries to represent each of the regions in Africa. The selected countries are Kenya, Morocco, Nigeria and South Africa. The total number of coronavirus cases during the pandemic era were used as a proxy for coronavirus $^{7}$. The dataset ranged from 02 January 2019 to

\footnotetext{
${ }^{3}$ World Bank identified skewness and volatility as common proxies for measuring of financial market stability, hence their choice as measures of financial market stability in this study (see: https://www.worldbank.org/en/publication/gfdr/gfdr-2016/background/financial-stability).

${ }^{4}$ The Africa stock market data were obtained from investing.com database. Information on the stock data is available online: https://www.investing.com/indices/african-indices.

${ }^{5}$ The sovereign bond data were collected from S\&P Dow Jones Africa sovereign bond index, which tracks the performance of local currency-denominated sovereign bonds from African countries (see more data description at:
}

31 August 2020, and were divided into three sub-periods. The first sub-period, ranged from 02/01/2019$30 / 12 / 2019$, captures the pre-coronavirus period. The second sub-period (02/01/2020 - 10/03/2020) captures the coronavirus endemic period. The third sub-period $(11 / 03 / 2020-31 / 08 / 202)$ captures the coronavirus pandemic period. The division of the study period was to enable analysis of the behaviour of Africa financial markets before coronavirus, the effect of coronavirus endemic and pandemic periods on Africa financial market returns and volatility. All the dataset were transformed to percentage daily return as first difference of natural logarithm series thus:

$$
\begin{gathered}
P r_{i, t}=\left(\operatorname{Ln}\left(F m p_{i, t}\right)-\operatorname{Ln}\left(F m p_{i, t-1}\right)\right) \\
* 100
\end{gathered}
$$

Where $\operatorname{Pr}_{t}$ is the daily percentage return for financial market asset $i, F m p_{i, t}$ is daily closing price of the financial market asset $i$ at time $t, F m p_{i, t-1}$ is previous day closing price of the financial market asset $i$, and $L n$ is natural $\log$.

\section{Results and discussion}

\section{Descriptive Statistics}

Tables 1a, 1b and 1c display descriptive statistics of the percentage return series for Africa stock markets, sovereign bond markets, and African currencies/dollar exchange rates for pre-coronavirus period, coronavirus endemic period, and coronavirus pandemic period. Notice from Table 1a that African daily average stock return for the pre-coronavirus period is positive and not skewed but became negative and negatively skewed during the endemic and pandemic periods. The skewness of a normal distribution is zero. Liu, Zhang, and Wen (2014) observe that negatively skewed return distribution will increase the loss probability, whereas positively skewed one will increase the possibility of gaining. During the coronavirus pandemic, the return distribution of all Africa stocks including Sharia stock prices were negatively skewed, implying that there were higher probability of large negative returns than positive returns. This finding is similar those from sovereign bonds and exchange rates.

Notice also the very wide gap between percentage minimum return in the three periods studied. In pre-

https://www.spglobal.com/spdji/en/index-family/fixed-income/).

${ }^{6}$ The South Africa rand and Kenya shilling/US dollar exchange rates were collected from their respective central banks. The Nigerian naira and Moroccan dirham/ US dollar exchange rates were collected from African Markets database, which provides financial market data, news, analysis and research with a focus on Africa (available online: https://www.african-markets.com/en/tools/currencies).

${ }^{7}$ The coronavirus data were collected from Our World in Data database available online: https://ourworldindata. org/coronavirus. 
Table 1a: Descriptive statistics for Africa Stock markets

\begin{tabular}{|c|c|c|c|c|c|}
\hline & Mean \% & Minimum & Maximum & Standard dev. & Skewness \\
\hline \multicolumn{6}{|c|}{ pre-coronavirus period } \\
\hline Africa & 0.0167 & -3.0579 & 3.3541 & 0.9653 & -0.0786 \\
\hline Kenya & -0.0248 & -1.4385 & 3.3612 & 0.6520 & $1.2327 *$ \\
\hline Morocco & 0.0236 & -1.7263 & 2.0273 & 0.5677 & $0.2559 * * *$ \\
\hline Nigeria & -0.0695 & -2.1630 & 4.2571 & 0.8529 & $0.7406^{*}$ \\
\hline South Africa & 0.0462 & -2.8302 & 2.1976 & 0.8491 & $-0.3575 * *$ \\
\hline Sharia & 0.0441 & -2.6108 & 6.5100 & 1.0864 & $0.8152 *$ \\
\hline \multicolumn{6}{|c|}{ Coronavirus endemic period } \\
\hline Africa & $-0.4564 * *$ & -6.1779 & 2.2992 & 1.4850 & $-2.0672 *$ \\
\hline Kenya & -0.3034 & -3.0550 & 1.3219 & 0.7878 & $-0.8137 * *$ \\
\hline Morocco & -0.1477 & -7.0565 & 6.6438 & 1.6761 & -0.2020 \\
\hline Nigeria & -0.2313 & -5.6982 & 3.9280 & 1.4391 & -0.4874 \\
\hline South Africa & -0.3134 & -6.7967 & 3.8914 & 1.7477 & $-1.4794 *$ \\
\hline Sharia & $-0.5676 * *$ & -7.0159 & 3.5472 & 2.0495 & $-1.1866^{*}$ \\
\hline \multicolumn{6}{|c|}{ Coronavirus pandemic period } \\
\hline Africa & 0.0838 & -12.1005 & 6.6378 & 2.5712 & $-1.3494 *$ \\
\hline Kenya & $-0.2180 * *$ & -5.1382 & 1.8894 & 1.1555 & $-1.4474 *$ \\
\hline Morocco & -0.0851 & -9.7900 & 3.9038 & 1.6793 & $-2.2448 *$ \\
\hline Nigeria & 0.0472 & -4.4642 & 3.4206 & 1.1075 & $-0.5811^{*}$ \\
\hline South Africa & 0.1320 & -10.4504 & 7.9071 & 2.4206 & $-0.8663^{*}$ \\
\hline Sharia & 0.0381 & -12.4327 & 5.3450 & 2.5925 & $-1.5472 *$ \\
\hline
\end{tabular}

Note: *,** and $* * *$ are $1 \%, 5 \%$ and $10 \%$ significance levels respectively

Table 1b: Descriptive statistics for Africa sovereign bond markets

\begin{tabular}{|c|c|c|c|c|c|}
\hline & Mean $\%$ & Minimum & Maximum & Standard dev. & Skewness \\
\hline \multicolumn{6}{|c|}{ pre-coronavirus period } \\
\hline Africa & $0.0672 *$ & -0.8732 & 1.5050 & 0.3583 & $0.4280^{*}$ \\
\hline Kenya & $0.0518 *$ & -0.6351 & 0.8467 & 0.1963 & -0.0037 \\
\hline Morocco & $0.0237 * *$ & -0.5430 & 0.7483 & 0.2140 & $0.2874 * *$ \\
\hline Nigeria & $0.1175^{*}$ & -1.6711 & 1.7560 & 0.4156 & $0.6644 *$ \\
\hline South Africa & 0.0499 & -4.3012 & 3.4363 & 1.0892 & -0.0934 \\
\hline Sukuk & $0.0368 *$ & -0.3914 & 0.3947 & 0.1142 & 0.0131 \\
\hline \multicolumn{6}{|c|}{ Coronavirus endemic period } \\
\hline Africa & -0.1302 & -3.219 & 1.0711 & 0.7838 & $-2.6679 *$ \\
\hline Kenya & 0.0308 & -0.6562 & 1.0802 & 0.2969 & $0.6463 * * *$ \\
\hline Morocco & 0.0373 & -0.3865 & 0.7052 & 0.2448 & $1.1287 *$ \\
\hline Nigeria & 0.0544 & -2.3103 & 2.0442 & 0.6478 & $-0.6121 * * *$ \\
\hline South Africa & -0.2775 & -3.5849 & 2.6584 & 1.2091 & -0.3610 \\
\hline Sukuk & $0.0455 * *$ & -0.5678 & 0.3310 & 0.1716 & $-1.5973 *$ \\
\hline \multicolumn{6}{|c|}{ Coronavirus pandemic period } \\
\hline Africa & 0.0627 & -7.2343 & 3.2798 & 1.3416 & $-2.1594 *$ \\
\hline Kenya & 0.0135 & -1.2092 & 0.9782 & 0.2995 & $-0.5820 *$ \\
\hline Morocco & 0.0600 & -1.2770 & 2.1706 & 0.4763 & 0.1360 \\
\hline Nigeria & 0.1175 & -7.4847 & 3.1229 & 1.0973 & $-3.1938 *$ \\
\hline South Africa & -0.0266 & -6.2113 & 5.9438 & 2.0181 & -0.3287 \\
\hline Sukuk & 0.0304 & -1.2907 & 0.5929 & 0.2417 & $-2.3413 *$ \\
\hline
\end{tabular}

Table 1c: Descriptive statistics for Africa currencies/dollar exchange rates

\begin{tabular}{|l|c|c|c|c|c|}
\hline & Mean \% & Minimum & Maximum & Standard dev. & Skewness \\
\hline \multicolumn{7}{|c|}{ pre-coronavirus period } \\
\hline Kenya & -0.0026 & -0.9055 & 0.9714 & 0.2022 & -0.1513 \\
\hline Morocco & 0.0010 & -0.8248 & 0.9525 & 0.2370 & -0.0985 \\
\hline Nigeria & -0.0011 & -10.0563 & 16.2212 & 1.5847 & $3.1333^{*}$ \\
\hline South Africa & -0.0111 & -2.3176 & 3.0563 & 0.8513 & $0.2617^{* * *}$ \\
\hline \multicolumn{7}{|c|}{ Coronavirus endemic period } \\
\hline Kenya & -0.4048 & 0.9835 & 0.2201 & $1.5545^{*}$ \\
\hline Morocco & 0.0316 & -0.5521 & 0.3207 & 0.2283 & $-0.8300^{* *}$ \\
\hline Nigeria & -0.0376 & -0.5068 & 0.5374 & 0.2144 & 0.2719 \\
\hline South Africa & 0.0180 & -1.7033 & 3.7405 & 1.0194 & $0.6611^{* * *}$ \\
\hline \multicolumn{7}{|c|}{ Coronavirus pandemic period } \\
\hline Kenya & $0.2673^{* * *}$ & -1.0234 & 0.8712 & 0.2708 & $-0.5404^{* *}$ \\
\hline Morocco & $0.0446^{* * *}$ & -1.6152 & 1.5556 & 0.4168 & $0.9700^{*}$ \\
\hline Nigeria & -0.0281 & -4.4703 & 3.9624 & 0.8425 & $-0.5765^{* *}$ \\
\hline South Africa & 0.0457 & -4.0441 & 3.7640 & 1.2739 & $0.3946^{* *}$ \\
\hline
\end{tabular}


coronavirus period, the minimum daily return for African stock price was $-3.06 \%$. But during the coronavirus endemic and pandemic periods, the minimum daily returns were $-6.17 \%$ and $-12.10 \%$ respectively. These highlights the magnitude of the negative skewness reported above. Apart from the African stock prices, the countries' stock prices exhibited very wide gap between the pre-coronavirus period and endemic and pandemic periods. Sharia index, for example, recorded $-2.661 \%,-7.01 \%$ and $-12.43 \%$ minimum daily returns for pre-coronavirus period and endemic and pandemic periods respectively. Similar wide minimum returns were observed for sovereign bonds and exchange rates return series. The percentage minimum return for Africa sovereign bond index for the pre-coronavirus period and endemic and pandemic periods are $-0.87 \%,-3.22 \%$, and $-7.23 \%$, respectively. But percentage minimum return for Sukuk was narrower than the Africa, Nigeria and South Africa sovereign bond indices.

The average daily volatility of sukuk prices for the pre-coronavirus period, endemic and pandemic periods were also smaller than those of Africa, Kenya, Morocco, Nigeria and South Africa sovereign bonds. This relates to Hassan et al. (2018) findings that sukuk offers a diversification benefit due to its lower volatility in returns in comparison to conventional bonds, but that the benefits decreases during periods of high volatility. The African currencies/US dollar exchange rate estimates show that the unconditional volatility is higher in the pandemic period, than in the endemic and pre-coronavirus periods. Similarly, the unconditional volatility of Africa stock returns are wider during the coronavirus pandemic period than in the other periods. In the same vein, the variability in stock returns is wider during the endemic period than in the pre-coronavirus period. These results are similar to Ampudia, Baumann and Fornari (2020) who noted that the standard deviation of daily equity returns of major indices in the euro area, the United States, the United Kingdom and Japan is at levels comparable to the peaks associated with the October 1987 stock market crash and the default of Lehman Brothers in September 2008. The decline in financial assets prices may have led to a large spike in the volatility of their returns.

\section{Impact of coronavirus on Africa financial markets returns and volatility}

Table 2 displays the results of bivariate regression model estimated to evaluate the impact coronavirus cases on selected Africa financial markets' return and volatility. The dependent variable is the Africa financial market return/volatility and the independent variable is the total number of coronavirus cases. Notice from panel A of table 2 that COVID-19 pandemic has negative and statistically significant impact on stock market returns for Morocco, Nigeria and South Africa. The Kenyan stock market return is also negatively impacted by the pandemic but the coefficient is not significant. These estimates suggest that increase in coronavirus cases results in negative stock returns in the African markets. Converse evidence is observed for Africa stock market returns volatility. COVID-19 pandemic has positive and significant impact on all the African stock markets' return volatility at the $1 \%$ significance level. The volatility results indicate that as number of coronavirus cases increases, volatility of Kenya, Morocco, Nigeria and South Africa stock returns also increases. This finding is related to Ali et al. (2020), who reported that returns of most of the global financial securities are negatively and significantly related to COVID-19 deaths. The finding is also similar to Topcu and Gulal (2020), who found that the coronavirus pandemic has a negative impact on emerging stock markets. Increasing volatility makes investors clamour for a higher risk premium in order to protect against increased uncertainty, which increases the cost of capital. Although Africa governments have unveiled different countermeasures to mitigate such negative impacts on the continent's stock returns volatility, it would be worthwhile to continually monitor the policies to ensure that they are effective in engendering financial stability in the region.

Notice also from panel $B$ of Table 2 that the returns on Africa sovereign bonds are all negative and significant at conventional levels, except for Kenya. Similar to the stock markets return, COVID-19 pandemic has negative and significant impact on African sovereign bonds return. The impact of COVID19 pandemic on all the African sovereign bonds' return volatility is positive and significant at the $1 \%$ level. These results also imply that as number of coronavirus cases increases volatility of Kenya, Morocco, Nigeria and South Africa sovereign bond returns also increases. Notice also that South Africa sovereign bond appears more volatile than the other African countries. This may be attributed to the number of coronavirus cases in the country, which is the highest in the continent as well as the level of development of her financial market, which is considered as the most efficient in the continent. This explanation is in line with Peress (2014) finding that information disseminated among investors are incorporated into stock prices. The sentiment generated by coronavirus-related information and the associated fear of financial market crash may have contributed to the heightened volatility of Africa sovereign bonds. To reduce vulnerability to future health crisis, African countries should adequately fund the strengthening of their health-care system.

Panel $C$ of table 2 displays the impact of COVID-19 pandemic on the Kenyan Shilling, Moroccan Dirham, Nigerian Naira, and South African Rand versus US Dollar exchange rates. Notice that African exchange rate return series are all positive and significant, except for Kenyan Shilling. Positive impact of 
Table 2. Results of bivariate regression of coronavirus cases on African financial markets

\begin{tabular}{llclc}
\hline & Coefficients & $\begin{array}{c}\text { Returns } \\
\text { t-statistics }\end{array}$ & Coefficients & $\begin{array}{c}\text { Volatility } \\
\text { t-statistics }\end{array}$ \\
\hline Kenya & Panel A: Stock market & \\
Morocco & -0.1763 & -0.3062 & $4.7188^{*}$ & 7.1481 \\
Nigeria & $-4.4636^{*}$ & -4.9703 & $51.9531^{*}$ & 10.6297 \\
South Africa & $-1.3898^{* * *}$ & -1.8568 & $6.2137^{*}$ & 10.0655 \\
& $-3.3901^{* * *}$ & -1.7747 & $47.6017^{*}$ & 16.1806 \\
Kenya & -0.0012 & Panel B: Sovereign bond & & \\
Morocco & $-0.0110^{*}$ & -0.7364 & $0.0041^{*}$ & 6.5398 \\
Nigeria & $-0.0113^{*}$ & -2.1628 & $0.0094^{*}$ & 6.0747 \\
South Africa & $-0.0364^{*}$ & -2.6560 & $0.0364^{*}$ & 10.3137 \\
& & Panel C: Exchange rates & $0.2952^{*}$ & 14.1315 \\
Kenya & 0.0017 & 1.1120 & $0.0049^{*}$ & 4.7896 \\
Morocco & $0.0087^{*}$ & 3.7881 & $0.0077^{*}$ & 8.4660 \\
Nigeria & $0.0126^{* *}$ & 2.4071 & $0.0675^{*}$ & 6.3074 \\
South Africa & $0.0178^{* *}$ & 1.995 & $0.0964^{*}$ & 9.1734 \\
\hline
\end{tabular}

Note: $* * *$ and $* * *$ refers to $1 \%, 5 \%$ and $10 \%$ statistical significance levels respectively.

COVID-19 on African currencies/US dollar exchange rate indicate that African currencies depreciated in value during the pandemic. An increase in number of coronavirus cases, for example, resulted in an increase in Naira/US dollar exchange rate. It thus requires more Naira to buy dollar. This is the element of depreciation of African currencies resulting from coronavirus pandemic. Currency depreciation hurts most African economies who have significant foreign-currency sovereign debt, as inflation and rising debt service increases the burdens and places downward pressure on their exchange rates. Panel $C$ of table 2 also shows that COVID-19 pandemic impacted positively on volatility of African currencies/US dollar exchange rate. As the coronavirus cases increases, volatility of African currencies/US dollar exchange rate was equally increasing. This finding is similar to Benzid and Chebbi (2020), who reported that an increase in the number of cases and deaths in the US, has a positive impact on the USD/EUR, USD/Yuan and USD/LivreSterling.

Although, it is conspicuous that coronavirus pandemic impacted negatively on Africa financial markets, the findings of this study calls for sober reflection on the weak structure of African economies, which reinforces vulnerability to external shocks. Africans pay the highest cost of fund in the sovereign bond market. African currencies fell freely during the pandemic. There is an urgent need for Africa to build a solid structure that will sustain migration from primary-commodity-exporting continent to value-addition and knowledge-intensive continent. Such effort will not only minimise external financial vulnerability but also conserve foreign exchange as some of the imported finished products would be manufactured in the continent. What economic sense does it make for Nigeria, for example, to export crude oil, use most of the export earnings to import refined petroleum, and then use the remaining earnings to intervene in the foreign exchange market to defend naira from depreciation?

\section{Conclusion}

This paper evaluates the impact of coronavirus on financial markets stability in Africa using descriptive statistics, EGARCH $(1,1)$ model and bivariate regression model during the January 022019 to August 312020 period. The study period was divided into three sub-period: pre-coronavirus, coronavirus endemic and coronavirus pandemic periods. The results evince negative impact of coronavirus pandemic on Africa financial markets stability, as the stock markets and sovereign bonds returns from Kenya, Morocco, Nigeria and South Africa faced southward, with significant depreciation in the African currencies/US dollar exchange rate. The results further show that Africa financial markets return volatility increases as the number of coronavirus cases increase. Hence, coronavirus has negative impact on financial markets' returns and exacerbated financial markets return volatility in the continent. This conclusion highlights the overriding role of functional health-care system in achieving sustainable economic development. African countries should adequately finance the strengthening of Africa healthcare system to reduce vulnerability to future health crisis. Beyond future pandemic risks, a quality health-care infrastructure is very important in building a resilient economic system. A situation where some African leader seek medical attention outside the continent cast doubt on the effectiveness of regional health-care system as well as on the implementation of priority policies.

Another major policy implication of this conclusion is the urgent need for Africa to build a solid structure that will sustain migration from primary-commodity-exporting continent to value-addition and knowledge-intensive continent. This effort will not only minimise external vulnerability but will also conserve foreign exchange as some of the imported products, such as coronavirus vaccine, would be manufactured in the continent. More so, there is need 
for African financial market authorities to continually monitor the countermeasures implemented to mitigate the impact of coronavirus on the continent's financial market to ensure that they are effective in engendering stability in the region. Such endeavour will not only unearth ineffective countermeasures but will also enable review of implementation quality.

\section{References}

1. ALI M., ALAM N., RIZVI S.A.R., 2020, Coronavirus (COVID-19): An epidemic or pandemic for financial markets. Journal of Behavioral and Experimental Finance, 27: 1-6.

DOI: $10.1016 /$ j.jbef.2020.100341.

2. AKHTARUZZAMAN M., BOUBAKER S., SENSOY A., 2020, Financial contagion during COVID19 crisis, in: Finance Research Letters.

DOI: $10.1016 /$ j.frl.2020.101604.

3. AMPUDIA M., BAUMANN U. FORNARI F., 2020, Coronavirus (COVID-19): Market fear as implied by options prices, in: ECB Economic Bulletin, 4, https:// www.ecb.europa.eu/pub/economic-bulletin/focus/20 20/html/ecb.ebox202004_02 26672a3808.en.html.

4. ARMAH B., 2020, Socio-economic implications of COVID-19 in Africa and policy recommendations for recovery, UN Economic Commission for Africa Paper Series.

5. BATUO M., MLAMBO K., ASONGU S., 2017, Linkages between financial development, financial instability, financial liberalisation and economic growth in Africa, in:. Research in International Business and Finance, 45: 168-179.

DOI: 10.1016/j.ribaf.2017.07.148

6. BENZID L., CHEBBI K., 2020, The impact of COVID-19 on exchange rate volatility: Evidence through GARCH model, https://papers.ssrn.com/ sol3/papers.cfm?abstract_id $=3612141$.

7. COLOMBAGE S.R.N., 2009, Financial markets and economic performances: Empirical evidence from five industrialized economies, in: Research in International Business and Finance, 23(3): 339-348.

DOI: 10.1016/j.ribaf.2008.12.002.

8. CONLON T., CORBET S., MCGEE R.J., 2020, Are cryptocurrencies a safe haven for equity markets? An international perspective from the COVID-19 pandemic, in: Research in International Business and Finance, 54, 101248.

DOI: $10.1016 /$ j.ribaf.2020.101248.

9. CONLON T., MCGEE R., 2020, Safe haven or risky hazard? Bitcoin during the Covid-19 bear market. Finance Research Letters, 35, 101607.

DOI: 10.1016/j.frl.2020.101607.

10. EMENIKE K. O., 2017, Weak-form efficiency after the global financial crises: Emerging stock market evidence. Journal of Emerging Market Finance, 16(1): 99-113, http://journals.sagepub.com/doi/pdf/10.1177 /0972652716686268.

11. ENGELBERG J., PARSONS C., 2011, The causal impact of media in financial markets. Journal of Finance, 66(1): 67-97.

DOI: $10.1111 / \mathrm{j} .1540-6261.2010 .01626 . x$.

12. GOODELL J.W., 2020, COVID-19 and finance: Agendas for future research. Finance Research Letters, 35, 101512.

DOI: $10.1016 / \mathrm{j}$. frl.2020.101512.

13. HAROON O., RIZVI S.A.R., 2020, COVID-19: Media coverage and financial markets behavior: A sectoral inquiry, Journal of Behavioral and Experimental Finance, 27: 1-6.
DOI: 10.1016/j.jbef.2020.100343.

14. HASSAN M. K., PALTRINIERI A., DREASSI A., MIANI S., SCLIP A., 2018, The determinants of comovement dynamics between sukuk and conventional bonds, The Quarterly Review of Economics and Finance, 68: 73-84. DOI: 10.1016/j.qref.2017.09.003.

15. ITO T., 2020, Impact of the coronavirus pandemic crisis on the financial system in the Eurozone. Journal of Corporate Accounting \& Finance, 31(4): 1-6. DOI: $10.1002 /$ jcaf.22466.

16. KREMEN V., SHKOLNYK I., SEMENOG A., KREMEN O., 2019, Evaluating the relationship between financial sustainability and socio-economic development of countries, in: Central European Economic Journal, 6(53): 25-38.

DOI: 10.2478/ceej-2019-0003.

17. LAHMIRI S., BEKIROS S., 2020, The impact of COVID-19 pandemic upon stability and sequential irregularity of equity and cryptocurrency markets, Chaos, Solitons \& Fractals, 138, 109936. DOI: 10.1016/j.chaos.2020.109936.

18. LIU Z., ZHANG T., WEN F., 2014, Time-Varying Risk Attitude and Conditional Skewness. Abstract and Applied Analysis, 2014: 1-11.

19. DOI: $10.1155 / 2014 / 174848$

20. MFW4A TRACKER, 2020, Africa Financial Sector Responses to COVID-19, https://www.mfw4a.org/ news/africa-financial-sector-responses-covid-19-mf w4a-tracker?utm_source=MFW4A+Newsletter+ Subscribers\&utm_campaign $=$ eff64772c0 0 -Newslet ter+English_COPY_09\&utm_medium=email\&utm term $=0 \_7 \mathrm{fda} 899 \mathrm{a} 3 \overline{7}$-eff64772 $\mathrm{c} 0-355433721$.

21. MIRZA N., NAQVI B., RAHAT B., RIZVI S.K.A., 2020 , Price reaction, volatility timing and funds' performance during Covid-19, Finance Research Letters, 36:101657. DOI: $10.1016 /$ j.frl.2020.101657.

22. MURINDE V., 2012, Financial development and economic growth: global and african experience. Journal of African Economies, 21(Suppl. 1): i10-i56. DOI: $10.1093 / \mathrm{jae} / \mathrm{ejr} 042$.

23. OBEID H., ISMAIL A., 2020, The impact of coronavirus on the financial markets, https://theconversation.com/the-impact-of-coronavirus-on-the-financial -markets-133183.

24. PERESS J., 2014, The media and the diffusion of information in financial markets: Evidence from newspaper strikes. Journal of $\mathrm{Fi}$ nance, 69(5): 2007-2043. DOI: 10.1111/jofi.12179.

25. STIGLITZ F., 2010, Final keynote lecture at the sustainable business series, Edinburgh international book festival, http://www.youtube.com/watch? $\mathrm{v}=$ SfjQ17L-74.

26. TETLOCK P.C., 2007, Giving content to investor sentiment: The role of media in the stock market. Journal of Finance, 62 (3): p.1139-1168. DOI: $10.1111 / \mathrm{j} .1540-6261.2007 .01232 . x$

27. TOPCU M., GULAL S.O., 2020, The impact of COVID-19 on emerging stock markets, Finance Research Letters, 36, 101691. DOI: $10.1016 / j$.frl.2020.101691

28. TYSON J., 2020, The impact of Covid-19 on Africa's banking system, ODI Insight, https://www.odi.org/ blogs/17013-impact-covid-19-africa-s-banking-system.

29. WU C., HUANG S., CHANG T., CHIOU C., HSUEH, H., 2020, The nexus of financial development and economic growth across major Asian economies: Evidence from bootstrap ARDL testing and machine learning approach, Journal of Computational and Applied Mathematics, 372, 112660. DOI: 10.1016/j.cam.2019.112660. 